\title{
Examining the Relationship Between Monitoring Learner Progress and Course Learning Outcomes Achievement
}

\author{
Shimaa Elaraby ${ }^{1 *}$ and Mona Hassan ${ }^{2}$ \\ 'Associate Professor, Medical Education Department, Faculty of Medicine, Suez Canal University, Ismailia, Egypt; \\ shimaa80me@yahoo.com \\ ${ }^{2}$ Assistant Professor, Physiological Department, Fakeeh College for Medical Sciences, Jeddah, Saudi Arabia
}

\begin{abstract}
Students of the first-year nursing program were recently experienced continuous and formative assessment through their training program. This is to improve the achievement of the students and the Course Learning Outcomes (CLOs). Therefore, the aim of the current study was to investigate the relationship between monitoring students' performance through continuous and formative assessments, student, and CLOs achievements. The study revealed a significant increase in the students' marks in all assessment methods after the mid-semester exams. In addition, the CLOs achievement is increased when the students got feedback.
\end{abstract}

Keywords: Feedback, Formative Assessment, Learning Outcomes, Student Assessment; Student Progress

\section{Background}

Assessment of health professionals must have a rigorous system which assessment results can rely on. This is due to the decisions about the performance of the students having a direct impact on the patients and health care ${ }^{1}$. Such decisions are collected from several points and are made based on a variety of sources of information. Policies and procedures should be developed to direct the panel and panelists to help them reach decisions ${ }^{2}$.

Thus, it is essential to maintain the progress of students in the higher education institutions at a good peace ${ }^{3}$. These can be attained via monitoring achieving learning outcomes which are the expected performance of the graduates. These relate to the five learning domains which are: knowledge, cognitive, interpersonal, and communication and psychomotor domains ${ }^{4}$. Different types of assessment are used to measure the achievement of students in these domains. All the assessment methods must be valid, reliable and fair to be suitable to measure the learning outcomes ${ }^{5}$. These types are direct and indirect assessment methods. CLOs are assessed directly by collecting data form students' performance in quizzes, Student Prepared Presentations (SPP), assignments, Team Based Learning (TBL), portfolios and written exams.
Indirect assessment of learning outcomes is of vital importance in measuring the student achievement ${ }^{6}$.

At the program level, the school can prove the attainment of program learning outcomes by a constructive approach calculating the CLOs achievements. Then CLOs achievement is calculated by the average approach. In the average approach, the average of the scores of the students in all assessment methods is calculated and should exceed the target (80\%) for example ${ }^{7}$. In addition, Outcome-based Education is the current model applied in health professions education. Therefore, assessment of CLOs and students' progress is a contemporary topic of international interest ${ }^{8}$. Due to the impact of student achievement on assessing Course Learning Outcomes (CLOs), the irregularly monitoring student performance will decrease CLOs achievement.

Although in most of the programs the achievement of CLOs is measured, this was not done till the end of the course. In the current study, we analyzed the results and took the necessary action before the end of the course through measuring students' progress to continuously improve the course before the final exams. We also investigated the relationship between monitoring students' performance, feedback, and reflection on the CLOs achievements in a course of health profession schools. 


\section{Methodology}

\subsection{Study Context}

The study was conducted in Fakeeh College for Medical Sciences. The target population was the first-year students in a nursing program. The number of students was 56 students. Assessment methods included continuous assessment such as: quiz, TBL, cases, PBL, reflection, SPP, in addition to written exams (midterm and final exams) in both semesters in 20192020. The indirect assessment method is measuring the students' perception of CLOs survey. The assessment plan in the nursing program level is based on PDCA cycle. The used program plan is based on the alignment between learning outcomes at the course level and the learning outcomes at the program level. The main purpose of this program plan is to improve the program based on the results of the assessment methods? . The planning phase begins with ensuring the alignment between PLOs, CLOs, and the teaching and assessment methods while in doing phase the exam schedules and submitting the exam papers are done. In the check phase, the Quality and Accreditation Unit reviews the assessment reports. In the fourth phase, the course instructor writes the course report, and the Head of the Department writes the annual report to discuss the recommendation and action plans for revisiting the planning phase and acting on the next exams ${ }^{10}$.

\subsection{Study Instruments}

The data was conducted through the calculations of students' scores in quizzes, TBL cases, PBL, reflection, and SPP, in addition to written exams (midterm and final exams). The data was anonymous. Moreover, we compared the CLOs achievements in two different courses taught in the same year with the same instructor.

\subsection{Statistical Analysis}

Data analysis was done with use of the Statistical Package for the Social Sciences (SPSS, version 20. IBM). Descriptive statistics was used for analyzing the study findings. T-test was used for estimating differences between means.

\subsection{Study Type}

A quantitative comparative study, where the effect of monitoring the achievements of CLOs early in the course was explored.

\subsection{Study population and sample type}

It was a nonprobability purposeful sample; respondents were a group of students (56), from the first year, one course (2 theory+ $1 \mathrm{CH}$ practical) with on-campus program, in the first semester as shown in Figure 1. The same students have been taught in the second semester, course with the same $\mathrm{CH}$ and the same instructor with frequent feedback. They experienced continuous assessment by a variety of assessment methods.

Sample Size: The whole batch was investigated in this study. Data collection tools:

- Document reviews.

- MCQs, essays, assignments, SPP.

- Feedback sessions were given orally to the students.

\section{Results}

\subsection{Courses' details}

The details of the two compared courses, title, code, credit, hours, level, semester, and number of students are shown in tables 1 and 2.

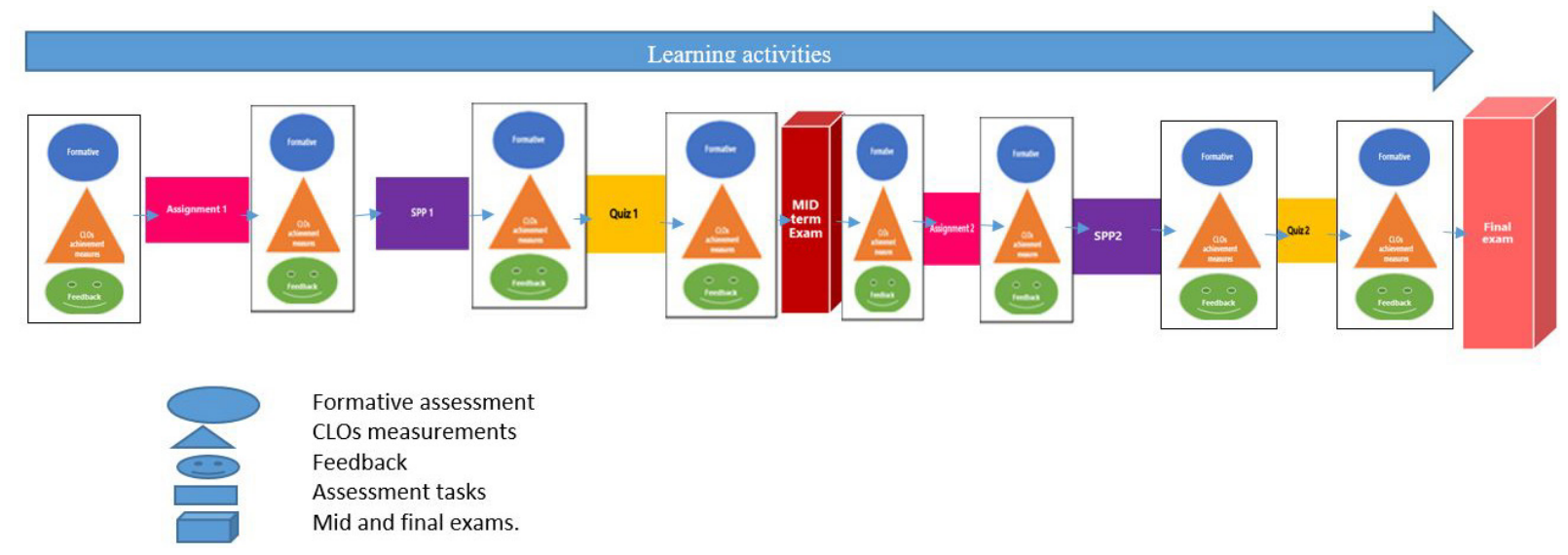

Figure 1. The flowchart of the investigated course 
Table 1. The Courses' Details

\begin{tabular}{|c|c|c|c|c|}
\hline Course title & $\begin{array}{c}\text { Credit } \\
\text { hours }\end{array}$ & Year & Semester & $\begin{array}{c}\text { Number of } \\
\text { students }\end{array}$ \\
\hline Course 1 & 3 & First & First & 56 \\
\hline Course 2 & 3 & First & Second & 56 \\
\hline
\end{tabular}

Table 2. The Assessment Plan in the Two Courses

\begin{tabular}{|c|c|c|c|}
\hline & Assessment task & Week Due & $\begin{array}{c}\text { Proportion of } \\
\text { Total Assessment }\end{array}$ \\
\hline 1 & $\begin{array}{c}\text { Oral presentation } \\
\text { (SPP) }\end{array}$ & $\begin{array}{c}\text { During the } \\
\text { semester }\end{array}$ & $10 \%$ \\
\hline 3 & $\begin{array}{c}\text { Poster presentation } \\
\text { (group) }\end{array}$ & $\begin{array}{c}\text { During the } \\
\text { semester }\end{array}$ & $10 \%$ \\
\hline 4 & $\begin{array}{c}\text { Midterm } \\
\text { examination } \\
\text { Assignments }\end{array}$ & $\begin{array}{c}\text { During the } \\
\text { semester }\end{array}$ & $10 \%$ \\
\hline 5 & Quizzes & $\begin{array}{c}\text { During the } \\
\text { semester }\end{array}$ & $10 \%$ \\
\hline 6 & $\begin{array}{c}\text { Final examination } \\
\text { (Theoretical) }\end{array}$ & $14-15$ & $40 \%$ \\
\hline Total & \multicolumn{1}{|c}{} \\
\hline
\end{tabular}

\section{Differences between mean scores in the assessment methods:}

The study revealed a significant difference in mean scores in quizzes, assignments and SPPs in the second semester course as shown in Table 3, 4 and 5.

Table 3. Student scores $(\mathrm{N}=56)$ in Quiz 1 and 2 in Course 2

\begin{tabular}{|c|c|c|c|c|c|c|}
\hline & \multicolumn{6}{|c|}{ Test Value $=0$} \\
\hline & \multirow[t]{2}{*}{$\mathrm{t}$} & \multirow[t]{2}{*}{ df } & \multirow[t]{2}{*}{$\begin{array}{c}\text { Sig. } \\
\text { (2-tailed) }\end{array}$} & \multirow[t]{2}{*}{$\begin{array}{c}\text { Mean } \\
\text { Difference }\end{array}$} & \multicolumn{2}{|c|}{$\begin{array}{c}\text { 95\% Confidence } \\
\text { Interval of the } \\
\text { Difference }\end{array}$} \\
\hline & & & & & Lower & Upper \\
\hline Quiz 1 & 40.216 & 55 & .000 & 3.964 & 3.77 & 4.16 \\
\hline Quiz 2 & 72.338 & 55 & .000 & 4.3464 & 4.226 & 4.467 \\
\hline
\end{tabular}

Results are expressed as raw scores of students in Quizzes in the second semester course (which feedback and measuring CLOs achievements are measured), data were analyzed using t-test.

Table 4. Student Scores $(\mathrm{N}=56)$ in Assignment 1 and 2 in Course 2

\begin{tabular}{|l|l|c|c|l|c|c|}
\hline & \multicolumn{3}{|l|}{ Test Value $=\mathbf{0}$} \\
\cline { 2 - 7 } & $\mathrm{t}$ & $\mathrm{df}$ & $\begin{array}{l}\text { Sig. } \\
(2-\text {-tailed })\end{array}$ & $\begin{array}{l}\text { Mean } \\
\text { Difference }\end{array}$ & \multicolumn{2}{l|}{$\begin{array}{l}\text { 95\% Confidence } \\
\text { Interval of the } \\
\text { Difference }\end{array}$} \\
\cline { 5 - 7 } & & & & & Lower & Upper \\
\hline Ass. 1 & 41.626 & 55 & .000 & 3.268 & 3.11 & 3.43 \\
\hline Ass. 2 & 32.345 & 55 & .000 & 2.5625 & 2.404 & 2.721 \\
\hline
\end{tabular}

Results are expressed as raw scores of students in assignments in the second semester course (which feedback and measuring CLOs achievements are measured), data were analyzed using t-test.
Table 5. Course 2: Students' Scores $(\mathrm{N}=56)$ in SPP1 and 2

\begin{tabular}{|l|c|c|c|c|c|c|}
\hline & \multicolumn{7}{|c|}{ Test Value = 0 } \\
\cline { 3 - 7 } & $\mathbf{t}$ & $\mathbf{d f}$ & $\begin{array}{c}\text { Sig. } \\
\text { (2-tailed) }\end{array}$ & $\begin{array}{c}\text { Mean } \\
\text { Difference }\end{array}$ & $\begin{array}{c}\text { 95\% Confidence } \\
\text { Interval of the } \\
\text { Difference }\end{array}$ \\
\cline { 5 - 7 } & & & & & Lower & Upper \\
\hline SPP 1 & 18.664 & 55 & .000 & 4.875 & 4.35 & 5.40 \\
\hline SPP 2 & 21.409 & 55 & .000 & 3.750 & 3.40 & 4.10 \\
\hline
\end{tabular}

Results are expressed as raw scores of students in SPPs in the second semester course (which feedback and measuring CLOs achievements are measured), data were analyzed using t-test.

\section{Difference between CLOs achievements in courses 1 and 2}

The following tables (table 6 and 7) show a significant deference in the CLO achievement (knowledge and cognitive) between the first and the second course.

Table 6. CLOs Achievement in Knowledge Domain in The Two Courses

\begin{tabular}{|c|c|c|c|c|c|c|}
\hline & \multicolumn{6}{|c|}{ Test Value $=0$} \\
\hline & \multirow[t]{2}{*}{$\mathrm{t}$} & \multirow[t]{2}{*}{ df } & \multirow[t]{2}{*}{$\begin{array}{l}\text { Sig. } \\
\text { (2-tailed) }\end{array}$} & \multirow[t]{2}{*}{$\begin{array}{l}\text { Mean } \\
\text { Difference }\end{array}$} & \multicolumn{2}{|c|}{$\begin{array}{l}\text { 95\% Confidence } \\
\text { Interval of the } \\
\text { Difference }\end{array}$} \\
\hline & & & & & Lower & Upper \\
\hline Course 2 & 44.710 & 57 & .000 & 42.644 & 40.73 & 44.55 \\
\hline Course 1 & 26.597 & 57 & .000 & 32.010 & 29.60 & 34.42 \\
\hline
\end{tabular}

Results are expressed as percentage of CLOs achievements in knowledge domain in the first and second semester courses (course 1, the feedback was not implemented and Course 2 feedback and measuring CLOs achievements were measured), data were analyzed using t-test.

Table 7. CLOs Achievement in Cognitive Domain in The Two Courses

\begin{tabular}{|c|c|c|c|c|c|c|}
\hline & \multicolumn{6}{|c|}{ Test Value $=0$} \\
\hline & \multirow[t]{2}{*}{$t$} & \multirow[t]{2}{*}{ df } & \multirow[t]{2}{*}{$\begin{array}{c}\text { Sig. } \\
\text { (2-tailed) }\end{array}$} & \multirow[t]{2}{*}{$\begin{array}{c}\text { Mean } \\
\text { Difference }\end{array}$} & \multicolumn{2}{|c|}{$\begin{array}{l}\text { 95\% Confidence } \\
\text { Interval of the } \\
\text { Difference }\end{array}$} \\
\hline & & & & & Lower & Upper \\
\hline Course 2 & 38.843 & 57 & .000 & 48.621 & 46.11 & 51.13 \\
\hline Course 1 & 26.588 & 57 & .000 & 32.001 & 29.59 & 34.41 \\
\hline
\end{tabular}

Results are expressed as percentage of CLOs achievements in cognitive domain in the first and second semester courses (course 1, the feedback was not implemented and Course 2 feedback and measuring CLOs achievements were measured), data were analyzed using t-test. 


\section{Discussion and Conclusion}

\subsection{Discussion}

In this study, we investigated the effects of monitoring course progress and performance on the achievement of CLOs.

In our program assessment, information from multiple resources to improve the learning outcomes achievements, is collected. It has four main purposes: improving the learning, informing the decision-makers about the effectiveness of the educational process in the program, proving that the assessment process is effective in showing the achievements of the students. Finally, the program assessment supports the strategic planning and accreditation process ${ }^{11}$.

Van der Vleuten et al. argued that there should be one master plan for the program to follow-up the students' acquirement of competencies. The assessment should be forming multiple points and the assessment methods are in a continuum of stakes. Putting in the consideration bias reduction strategies to reduce the subjectivity of scoring ${ }^{12}$. This is consistent with our study, where the assessment committees ensure the alignment between PLOs and CLOs, then the course coordinators follow the assessment plan to monitor the CLOs achievement. In another study by Tweed \& Wilkinson who mentioned that the intuitions should follow a process based on the several pieces of information to make the pass/fail decision of students to decrease the subjectivity of the scoring in the current study we collected scores from a variety of assessment methods throughout the course contributes ${ }^{2}$.

In the present study, it was noticed that the means of marks of all assessment methods has been improved with the feedback. Feedback is proved to improve learning, performance, behaviors and consequently achievements. The feedback conversation enhances the awareness of the students about their roles if a good facilitator is involved in the conversation ${ }^{13}$. The results of this study are in compatible with the results of a study that investigated the effects of using learning analytics and giving feedbacks on the at-risk students ${ }^{14}$. The results of this study revealed that the performance of at-risk students improved after knowing their grades weekly.

Farooq stated that weighted average method is a simple way assess CLOs. It is conducted through calculating the proportions of all assessment tools. In the current study, we used this method to follow-up the students" progress in achieving the CLOs ${ }^{8}$.

Van Der Vleuten divided the purposes of intermediate assessments into three categories. First, as a diagnostic purpose to know how the learning is going, second as a therapeutic to remedy any defect in student learning, third as a prognostic to prevent the deficit in the final assessments ${ }^{15}$.
The assessment committee is responsible for putting remediation action with the collaboration with the mentors. The feedback is personalized, and the student is engaged in the action plan. This is compatible with our study which we provide feedback after each assessment point with the action plan and remediation.

For Continuous Quality Improvement, useful and relevant feedback should be related to the assessment and learning. By doing this, the feedback guarantees the students levels on the development continuum ${ }^{16}$.

In this study, we focused on the importance of monitoring student progress in health profession education. Moreover, this helps in improving the students' performance and will affect program evaluation through early discourse of the achievement of learning outcomes. The data collected from the students' performance were used to measure the CLOs achievement. Therefore, students' progress should be monitored early to increase CLOs achievement. This could be through variety of assessment methods such as quizzes, assignment, midterm exam. However, immediate feedback is required to enhance the student scores.

This study has some limitations; the study investigated only two courses in monitoring the progress of the students' performance. More studies are required to involve more courses for showing the effect of feedback on different learning contexts.

\subsection{Conclusion}

There is a substantial rising need to provide student feedback. Hence, establishing a system to document, monitor, evaluate, and report feedback is mandatory to monitor the student progress. Moreover, measuring CLOs achievement is an important part of closing the loop of student assessment. Taken together, instructors should collaborate with the students to improve their performance and achievements.

\section{Authors' Contribution}

SE constructed the design of this research, collected, analyzed data, and wrote the first draft of the manuscript. MH collected, analyzed data, and reviewed the manuscript. The final manuscript was read and approved by the authors.

\section{Ethical Considerations}

The study was approved by the Institutional Research Board at FCMS. The data collection tools were anonymous. Personal data will not be published under any circumstances. The extracted data from the records will be used for scientific 
publishing and educational reform. No harmful consequences are expected from this work.

\section{Funding}

No fund.

\section{Conflict of interest}

No conflict of interest.

\section{Acknowledgment}

The authors acknowledge the contributions from the participants who shared in this study.

\section{Reference}

1. Yudkowsky, R., Park, Y. S., \& Downing, S. M. (Eds.). Assessment in health professions education. 2019. Routledge.

2. Tweed, M., \& Wilkinson, T. Student progress decision-making in programmatic assessment: can we extrapolate from clinical decision-making and jury decision-making? BMC medical education, 2019. 19(1), 176.

3. Beekhoven, S., De Jong, U. \& Van Hout, H. Different courses, different students, same results? An examination of differences in study progress of students in different courses. Higher Education 46, 37-59 (2003). https://doi.org/10.1023/A:1024414529666

4. Operational Excellence and Assessment Support NCAAA standard document [Online]. Available: http://ncaaa.org.sa

5. Shumway, J Harden, Ronald AMEE Guide No. 25: The assessment of learning outcomes for the competent and reflective physician. Medical Teacher. 2003. https://doi.org/10.1080/01421 59032000151907
6. Vereijken, M.W.C., van der Rijst, R.M., van Driel, J.H. et al. Student learning outcomes, perceptions and beliefs in the context of strengthening research integration into the first year of medical school. Adv in Health Sci Educ 23, 371-385 (2018). https:// doi.org/10.1007/s10459-017-9803-0

7. Alzubaidi, L. Measurement of course learning outcomes for data structure using the combination approach. Int. J. Netw. Secur. (IJCSNS), 2016.16(1), 57.

8. Farooq, Q. U., \& Naqash, M. T. (2018). Comparison of Numerical Assessment and Periodic Progress of Specific Course Learning Outcomes for Introductory and Reinforce Level Engineering Courses. Education, 2018. 8(3), 42-47.

9. Goff L, Potter MK, Pierre E, Carey T, Gullage A, Kustra E, Lee R, Lopes V, Marshall L, Martin L, Raffoul J. Learning outcomes assessment a practitioner's handbook. 2015

10. Self-Study Report for Program, Fakeeh College for Medical Sciences; 2020.

11. University of Central Florida. UCF Academic Program Assessment Handbook February 2008.

12. Van Der Vleuten, C. P. M., et al. "Twelve Tips for programmatic assessment." Med Teach. 2015. 37(7): 641-646.

13. Walsh, K. (Ed.). Oxford textbook of medical education. Oxford University Press. 2013

14. Russell, J.-E.; Smith, A.; Larsen, R. Elements of Success: Supporting at-risk student resilience through learning analytics. Computers \& Education, [s. 1.], v. 152, 2020. https://doi. org/10.1016/j.compedu.2020.103890

15. C. P. M. van der Vleuten, L. W. T. Schuwirth, E. W. Driessen, J. Dijkstra, D. Tigelaar, L. K. J. Baartman \& J. van Tartwijk. A model for programmatic assessment fit for purpose, Medical Teacher, 2012. 34:3, 205-214, https://doi.org/10.3109/01421 59X.2012.652239

16. Norcini J, Anderson MB, Bollela V, Burch V, Costa MJ, Duvivier R, Hays R, Palacios Mackay MF, Roberts T, Swanson D. 2018 Consensus framework for good assessment. Medical teacher. 2018 Nov 2; 40(11): 1102-9. 